\title{
Description of the pupae of Anthrax oedipus oedipus Fabricius and Anthrax oedipus aquilus Marston (Diptera, Bombyliidae, Anthracinae)
}

\author{
Carlos José Einicker Lamas ${ }^{1}$ \\ Márcia Souto Couri ${ }^{1,2}$
}

\begin{abstract}
The pupae of Anthrax oedipus oedipus Fabricius, 1805 and Anthrax oedipus aquilus Marston, 1970 are described and illustrated. Eleven species of four Hymenoptera families (Apidae, Eumenidae, Megachilidae and Sphecidae) are recorded as hosts of the immature stages of A. o. oedipus and A. o. aquilus.

KEY WORDS. Diptera, Bombyliidae, Anthrax oedipus, pupa morphology
\end{abstract}

During the last few decades the most important contributions to the knowledge of the genus Anthrax Scopoli, 1763 were the ones of MARSTON (1970, 1971), Hull (1973) and HALL (1976). The New World species were revised by MARSTON (1970), with references to the larvae of oedipus group as parasites of a wide range of Hymenoptera. MARSTON (1971) described the pupae of fourteen species of Anthrax belonging to cephus, oedipus and tigrinus groups and presented a key to segregate them and four previously described species of the albofasciatus and trimaculatus groups. Regarding the oedipus group, four pupae were described: A. irrotatus irrotatus Say, 1823, A. cintalpa Cole, 1957, A. peruvianus Marston, 1970, A. cordillerensis Marston, 1970. The pupae were mainly characterised based on the shape of the cephalic and anal tubercles. HuLL (1973) listed some Anthracinae genera with their respective hosts and presented a key to Bombyliidae subfamilies with known pupae. Some illustrations were also provided. HaLL (1976) diagnosed the adults of $A$. o. oedipus Fabricius, 1805, but no mention to the morphology of the immature stages were made.

The present study is a contribution to the knowledge of the morphology of Bombyliidae immature stages throughout the description and illustrations of the pupae of A. oedipus oedipus and A. o. aquilus Marston, 1970 and also by the record of 11 species of four different Hymenoptera families as their hosts.

\section{MATERIAL}

This paper is based on a material collected in traps like nests made of bamboo, in forest fragments in Brazil (Viçosa, Minas Gerais and Serra do Japí, São Paulo) in two distincts projects: one from Universidade Federal de Viçosa (Minas Gerais, Brazil) and the other from Universidade de São Paulo (São Paulo, Brazil).

1) Museu Nacional. Quinta da Boa Vista, São Cristóvão, 20940-040 Rio de Janeiro, Rio de Janeiro, Brasil.

2) Conselho Nacional de Desenvolvimento Científico e Tecnológico (CNPq) fellow. 
All the examined material is deposited in the Museu Nacional, Rio de Janeiro, Brazil collection (MNRJ) and in the University Campus of Ribeirão Preto, São Paulo, Brazil collection (USP).

\section{Anthrax oedipus oedipus Fabricius, 1805}

\section{Figs $1-4$}

Pupa (Fig. 1). Length: 13.2-15.0 mm. Head width: 2.1-3.1 mm. Thorax width 2.6-3.6mm. Abdominal width: $2.6-3.6 \mathrm{~mm}$, tapering to $0.8-1.1 \mathrm{~mm}$ at width of anal segment. Coloration: predominant light brown; cephalic and anal tubercles and dorsal abdominal chitinous rods dark brown; setae yellowish brown.

Head. Armed with three pairs of spines fused basally to form a concave arch; anterior spines twice longer than the medial ones, tapering to sharp apex; medial spines broader basally, twice longer than the posterior ones, tapering to sharp apex; posterior spines short, with sharp apex (Fig. 2). Arch of the cephalic spines with two pairs of setae in dorsal surface (Fig. 1); anterior facial setae arising distinctly anterior to bases of anterior facial tubercles.

Thorax. With two pairs of anterodorsal setae (Fig. 1); prothoracic spiracle heavily sclerotized, raised above surface and located directly posterior to head.

Abdomen. Segment I dorsally with a row of long setae on the anterior margin (Fig. 1); segments II-V with a central row of concave arched chitinous rods, oriented longitudinally, extending transversely across dorsum of segment onto upper lateral portions, gradually becoming smaller, these chitinous rods are intercalated with setae, except in the central $1 / 3$, tuft of setae laterally; segment VI with only one chitinous rod dorsally in the central portion and a complete row of long setae extending onto the anterior portion of the next segment, tuft of setae laterally; segment VII without chitinous rods, dorsally there is only a complete row of long setae extending onto the anterior portion of the next segment, tuft of setae laterally; segment VIII dorsally with a central chitinous protuberance in the posterior portion and with setae in front of dorsolateral tumidities, tuft of setae laterally; segment IX (anal segment) with two tubercles, each one possessing a great central spine forceps like, two pairs of smaller spines appears basally in this central one, the ventrolateral pair is almost twice shorter than the dorsal one (Figs 3, 4). Abdominal spiracles slightly darker sclerotized than surrounding area, flush with surface, present laterally on segments I-VII.

Hosts. Hymenoptera - Apidae (Euglossa annectans Dressler, 1982), E. townsendi Cockerell, 1904, E. truncata Rebêlo \& Moure, 1995 and Euglossa sp.); Megachilidae (Megachile guaranitica Schrottky, 1908, M. pseudoanthioides Moure, 1943 and Megachile sp.); Sphecidae (Trypoxylon nitidum Smith, 1856, T. rogenhoferi Kohl, 1884 and Trypoxylon sp.); Eumenidae (Pachodynerius brevitho$\operatorname{rax}$ (Saussure), 1852).

Examined material. BRAsIL, Minas Gerais: Viçosa, 05-I-1992, 1 fêmea, R. Pérez - Maluf leg. (MNRJ); São Paulo: Jundiaí (Serra do Japí), III-VIII-1995, 1 fêmea e 2 machos, Camillo, Augusto e Serrano leg. (USP). 


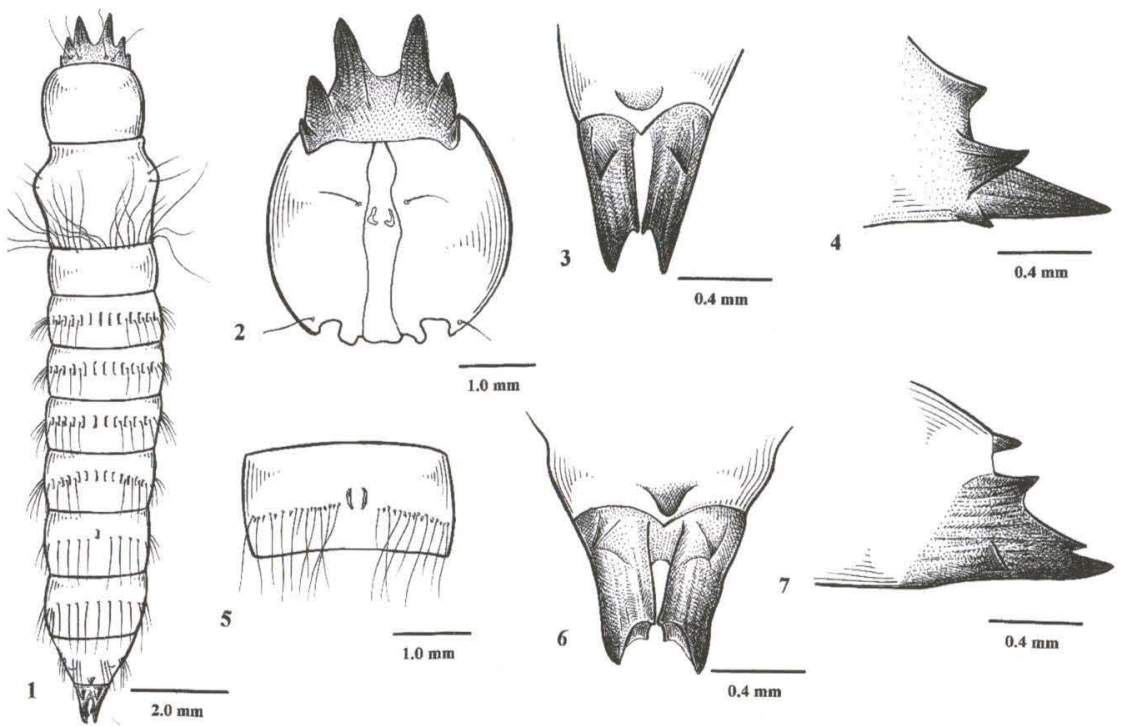

Figs 1-7. Pupae. (1-4) Anthrax oedipus oedipus: (1) general dorsal view; (2) head, ventral view; (3) anal tubercle, dorsal view; (4) anal tubercle, lateral view. (5-7) A. oedipus aquilus: (5) abdominal segment $\mathrm{VI}$, dorsal view; (6) anal tubercle, dorsal view; (7) anal tubercle, lateral view.

\section{Anthrax oedipus aquilus Marston, 1970}

Figs 5-7

Pupa. Length: 15.2-17.9 mm. Head width: 2.7-3.4 mm. Thorax width 3.1-3.8 $\mathrm{mm}$. Abdominal width: $3.0-3.7 \mathrm{~mm}$, tapering to $0.8-1.3 \mathrm{~mm}$ at width of anal segment.

Differs from A. o. oedipus in the following: abdominal segment VI dorsally with two chitinous rods and small spines intercalated with the setae (in some specimens these spines may not occur in all spaces between the setae) (Fig. 5); segment IX (anal segment) with two tubercles, each one possessing a great central spine forceps like with a third projection oriented ventrally (Figs 6, 7).

Hosts. Hymenoptera - Apidae (Euglossa truncata Rebêlo \& Moure, 1995, Euglossa sp.); Sphecidae (Trypoxylon sp.).

Examined material: BRASIL, São Paulo: Jundiaí (Serra do Japí), III-VIII1995, 1 fêmea (MNRJ), 2 fêmeas e 1 macho (USP), Camillo, Augusto e Serrano leg..

\section{DISCUSSION}

Morphological variation among pupae of Anthrax species has been mainly noted in the form and spatial distribution of anal and cephalic tubercles, and also on the posterior abdominal terga (MARSTON 1971). 
The differences showed by the pupae of Anthrax oedipus oedipus and Anthrax oedipus aquilus, can be easily distinguished on the basis of the tubercles pattern of the anal segment, in the number of chitinous rods on abdominal tergite VI and also by the presence / absence of small simple spines between setae on the abdominal tergite VI. Anthrax oedipus aquilus together with Anthrax cordillerensis are the only known species of oedipus group, with such small simple spines between setae on the abdominal tergite VI of pupa.

ACKNOWLEDGMENTS. We are grateful to Dr. Carlos Alberto Garófalo (Faculdade de Filosofia, Ciências e Letras de Ribeirão Preto, Universidade de São Paulo, São Paulo) and Dr. Rui Carlos Peruquetti (Universidade Federal de Viçosa, Minas Gerais) for the possibility to study this material and also for the donation of some specimens to the Museu Nacional collection. We also thank to Mr. Luiz Antônio Alves Costa for the help with illustrations.

\section{REFERENCES}

Hall, J.C. 1976. The Bombyliidae of Chile. Univ. Calif. Publs. Ent. 76: 1-278. Hull, F.M. 1973. The beeflies of the world. The genera of the family Bombyliidae. Bull. U.S. Nat. Mus. 286: 3-687.

MARston, N. 1970. Revision of the New World species of Anthrax (Diptera, Bombyliidae), other than the Anthrax albofasciatus group. Smithson. Contr. Zool. 43: 1-148.

. 1971. Taxonomic study of the known pupae of the genus Anthrax (Diptera: Bombyliidae) in North and South America. Smithson. Contr. Zool. 100: $1-18$.

Recebido em 19.III.1998; aceito em 31.VIII.1999. 